\title{
Soluble proteins of bronchopulmonary secretions from patients with cystic fibrosis, asthma, and bronchitis
}

\author{
T. D. B R O G A , H. C. R Y LEY, L Y N N N EALE, \\ and JANET YASSA \\ Departments of Medical Microbiology and Child Health, Welsh National School of Medicine, \\ University Hospital of Wales, Cardiff
}

\begin{abstract}
Brogan, T. D., Ryley, H. C., Neale, Lynne, and Yassa, Janet (1975). Thorax, 30, 72-79. Soluble proteins of bronchopulmonary secretions from patients with cystic fibrosis, asthma, and bronchitis. The concentrations of nine plasma proteins were determined by quantitative immunoelectrophoresis in sputum specimens from 29 patients with cystic fibrosis (CF) and from 24 patients with severe asthma and chronic bronchitis. The results suggested that the population of CF patients could be divided into two groups in spite of an absence of difference in clinical status between the groups. Average concentrations of seven plasma proteins in sputum of group I CF patients were identical with those in sputum of patients with bronchitis, but the average concentrations of six of these proteins in sputum from group II CF patients were higher than those in specimens from the bronchitic patients and were similar to corresponding concentrations in sputum from patients with asthma, all of whom were examined while in status asthmaticus. The average concentrations of 14 secretory proteins were the same in all sputum specimens whether or not they were produced by patients with cystic fibrosis, asthma or bronchitis.

It was concluded that the concentrations in the bronchopulmonary secretions of proteins associated with host defence were not diminished in patients with cystic fibrosis, and failure to produce adequate concentrations of proteins with antimicrobial activity was unlikely to be responsible for the above average susceptibility to chest infection in cystic fibrosis. It is suggested that there exists a group of CF patients in whom a pulmonary allergic reaction generates an inflammatory response as severe as that characterizing status asthmaticus and that this response could be detrimental.
\end{abstract}

Cystic fibrosis (CF) occurs with a frequency of approximately $1: 2000$ live births, thus making the condition one of the more common congenital diseases. It appears likely that the diverse pathology of the disease can be explained by a single defect or group of defects that results in the production of abnormal mucus secretion throughout the body. Life expectancy of patients affected with cystic fibrosis has increased since the condition was first recognized as a disease by Andersen (1938) but the condition is still lethal and the most common cause of death is an overwhelming chest infection.

It is possible that the abnormal mucus pro- duced by cystic fibrosis patients initiates and causes a form of obstructive airways disease that ${ }^{\circ}$ predisposes to respiratory infection. A similar 0 sequence of events is believed to be responsible $\mathbb{E}_{\tilde{N}}^{\mathrm{N}}$ for the infective exacerbations of chronico bronchitis (May, 1958). However, severity of in fection in cystic fibrosis appears to be greater than expected as compared with diseases such as $\stackrel{\oplus}{+}$ chronic bronchitis, and, furthermore, the patho- 0 gens involved in the chest infections differ from those associated with chronic bronchitis (Burns $\stackrel{\mathbb{\triangle}}{\mathscr{Q}}$ and May, 1968).

In the present investigation the sol phase of mucus that separates on ultracentrifugation 
(Ryley and Brogan, 1968) was examined in a series of cystic fibrosis patients. This portion of the mucus is virtually the continuous phase of the ground substance and contains the salts and soluble proteins of the altered bronchial secretion. The study was carried out to see whether or not the soluble proteins of cystic fibrosis mucus differed qualitatively or quantitatively from those found in sputum from patients with severe asthma and chronic bronchitis.

\section{PATIENTS AND METHODS}

PATIENTS Twenty-nine cystic fibrosis patients were studied; their average age was $8 \pm 4.6$ years and the number of girls was 11. Eleven of the patients were deemed to be severely affected by the disease in that they were allocated low scores $(0-2)$ in the simplified CF scoring scale (Cooperman et al., 1971); seven of these children died during or shortly after the completion of the study.

Twenty-four patients with asthma and bronchitis were also investigated. Twelve of the patients were diagnosed as asthmatic on the criterion of intermittent airways obstruction and their admission to hospital was precipitated by status asthmaticus; sputum specimens were obtained from these patients during the episode of acute exacerbation. The average age of the patients with asthma was $53 \pm 16$ years and the number of women patients was 7 . The remaining 12 patients were diagnosed as suffering from chronic bronchitis on the criteria of the MRC Committee on the Aetiology of Chronic Bronchitis (1965). All were hospital inpatients with an average age of $63 \pm 10$ years and the number of women patients was 2 .

SPUTUM SPECIMENS A 24-hour collection of sputum was carried out on the patients suffering from bronchitis and asthma. Collection of sputum over a 24-hour period was rarely practicable in patients with cystic fibrosis, many of whom were small children. In most cases, collection of specimens from cystic fibrosis patients was made during and after morning physiotherapy.

All specimens were taken to the laboratory immediately after the collection, and weighed aliquots of sputum were centrifuged at $120,000 \mathrm{~g}$ (average rotor radius $=8.5 \mathrm{~cm}$ ) using the $S W 50$ rotor in a model L2 Spinco ultracentrifuge (Beckman Instruments Ltd., California, USA) for three-and-a-half hours at $4^{\circ} \mathrm{C}$ (Ryley and Brogan, 1968). Specimens from cystic fibrosis patients were centrifuged in Beckman plastic adaptors of $1 \mathrm{ml}$ volume that were designed to fit the buckets of the SW 50 rotor. The sol phase was removed and the proportion of mucus that separated as gel phase was estimated by weighing.

Quantitative immunoelectrophoresis of the soluble proteins of sputum The reagents and methods used in the quantitative immunoelectrophoresis of the soluble proteins of sputum were substantially the same as those described in detail by Ryley (1972) and Ryley and Brogan (1973). Plasma and secretory protein concentrations were mostly estimated by the crossed immunoelectrophoretic technique of Clarke and Freeman (1968), which was carried out on $10 \times 10 \mathrm{~cm}$ glass slides using $4 \mu \mathrm{l}$ volumes of sputum sol phase. Anti-human serum protein antiseruum, $0.2 \mathrm{ml}$, or $1 \mathrm{ml}$ of anti-sputum secretory protein antiserum was incorporated into the antibody agarose phase and, after electrophoresis, the areas under the arcs were measured by projection.

The concentrations of the plasma proteins were estimated as milligrams per 100 millilitres from standard curves that were prepared by using standard serum (Hoechst Pharmaceuticals Ltd., Portland House, London, SW11); relative concentrations of secretory proteins were estimated in a similar manner using a 'standard' sputum sol phase. $\alpha_{1}$ acid glycoprotein, lactoferrin, lysozyme, and IgG were all measured by electroimmunoassay against monospecific antisera (Lopez, Tsu and Hyslop, 1969).

\section{RESULTS}

The average proportion of ground substance separating as gel phase on ultracentrifugation was $26 \pm 16 \%$ regardless of whether the sputum was produced by patients with cystic fibrosis, asthma or bronchitis. The crossed immunoelectrophoretic patterns of sputum sol phase secretory proteins were closely similar in cystic fibrosis, asthma, and bronchitis and the same 14 components (Ryley, 1972) could be distinguished; their relative concentrations did not vary significantly between sputum specimens obtained from patients suffering from any of the three groups of chest diseases. The typical plasma protein pattern of the sol phase of sputum from patients with cystic fibrosis is illustrated in Figure 1. It quickly became apparent that the cystic fibrosis patients fell into two groups; one group consistently yielded sputum specimens with low albumin concentrations whereas the sputum specimens from the other group contained high levels of albumin. Analysis of preliminary results showed that $50 \mathrm{mg}$ albumin/ $100 \mathrm{ml}$ was two standard deviations above the mean albumin concentration of the first group; $50 \mathrm{mg}$ albumin/100 $\mathrm{ml}$ was therefore used as a criterion to divide the cystic fibrosis patients into two categories; those with sputum albumin concentrations consistently less than this value were called group I CF patients and those with sputum albumin levels consistently in excess of $50 \mathrm{mg} /$ $100 \mathrm{ml}$ were called group II CF patients. The two groups did not differ significantly in average age or sex ratio or in the proportion of patients severely affected by the disease. 


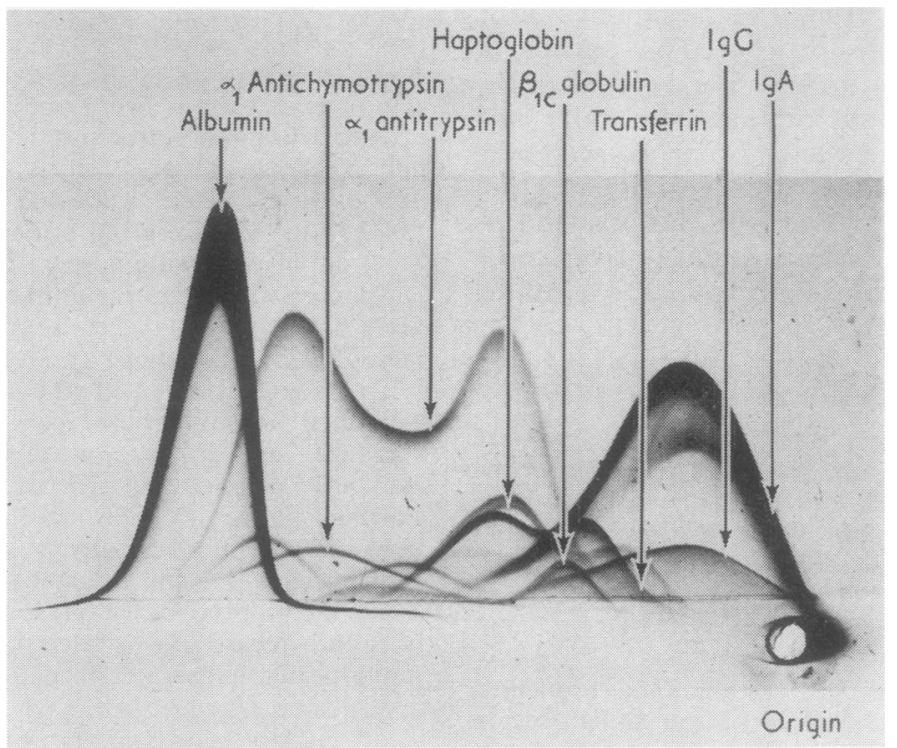

FIG. 1. Photograph of a cross immunoelectrophoretic pattern of the sol phase of sputum from a patient with cystic fibrosis (group I) showing eight of the nine plasma proteins commonly found in the continuous phase of the ground substance. Anti-human serum protein antiserum was incorporated into the antibody agarose phase. The bifid $\alpha_{1}$ antitrypsin arc is characteristic of cystic fibrosis sputum and is probably caused by complex formation between the antiprotease and proteolytic enzymes. Sol phase of sputum from group II CF patients when diluted threefold gave a similar pattern to the one above.

CONCENTRATIONS OF SOLUBLE PROTEINS IN THE SPUTUM SOL PHASE The average concentrations of albumin, transferrin, and the acute phase proteins ( $\alpha_{1}$ acid glycoprotein and haptoglobin) in sputum from group I CF patients did not differ significantly from those in sputum from patients with bronchitis (Table I); the average concentration of the enzyme inhibitor $\alpha_{1}$ antitrypsin was significantly greater in sputum from group I CFO patients than in sputum from patients with $\underset{\times}{\infty}$ bronchitis $(0.01<\mathrm{P}<0.02)$ but the sputum con-o centrations of $\alpha_{1}$ antichymotrypsin did not differ significantly. In contrast, the average concentra-ô tions of albumin, transferrin, and the acute phase proteins were all significantly greater $(P<0.001)$ 을 in the sol phase of sputum from group II $\mathrm{CF}$

T A B L E I

CONCENTRATIONS OF SIX PLASMA PROTEINS IN THE SOL PHASE OF SPUTUM FROM CYSTIC FIBROSIS PATIENTS COMPARED WITH THOSE OF SPUTUM FROM PATIENTS WITH ASTHMA AND CHRONIC BRONCHITIS

\begin{tabular}{|c|c|c|c|c|}
\hline \multirow[b]{3}{*}{ Plasma Protein } & \multicolumn{4}{|c|}{ Average Concentrations $(\mathrm{mg} / 100 \mathrm{ml})$ in the Sol Phase } \\
\hline & \multicolumn{2}{|c|}{ Sputum from Patients with Cystic Fibrosis } & \multicolumn{2}{|c|}{ Sputum from Patients with Asthma and Bronchitis } \\
\hline & $\begin{array}{c}\text { Group I } \\
\text { (15 patients) } \\
\text { Mean } \pm \text { SD }\end{array}$ & $\begin{array}{c}\text { Group II } \\
\text { (14 patients) } \\
\text { Mean } \pm \text { SD }\end{array}$ & $\begin{array}{c}\text { Asthma } \\
\text { (12 patients) } \\
\text { Mean } \pm \text { SD }\end{array}$ & $\begin{array}{c}\text { Bronchitis } \\
\text { (12 patients) } \\
\text { Mean } \pm \text { SD }\end{array}$ \\
\hline $\begin{array}{l}\text { Albumin } \\
\text { Transferrin } \\
a_{1} \text { acid glycoprotein } \\
\text { Haptoglobin } \\
a_{1} \text { antitrypsin } \\
a_{1} \text { antichymotrypsin }\end{array}$ & $\begin{array}{l}23 \pm 15 \\
2 \cdot 3 \pm 1 \cdot 5 \\
1 \cdot 5 \pm 1 \cdot 5 \\
2 \cdot 0 \pm 2 \cdot 9 \\
9 \cdot 4 \pm 9 \cdot 3 \\
1 \cdot 6 \pm 1 \cdot 4\end{array}$ & $\begin{array}{l}109 \pm 63 \\
7 \cdot 5 \pm 5 \cdot 8 \\
6 \cdot 1 \pm 5 \cdot 7 \\
11 \pm 14 \cdot 3 \\
24 \pm 19 \cdot 8 \\
2 \cdot 8 \pm 3 \cdot 7\end{array}$ & $\begin{array}{l}138 \pm 100 \\
6 \cdot 9 \pm 3 \cdot 9 \\
3 \cdot 5 \pm 3 \cdot 4 \\
6 \cdot 5 \pm 6 \cdot 3 \\
11 \pm 6 \cdot 1 \\
4 \cdot 5 \pm 1 \cdot 8\end{array}$ & $\begin{array}{l}24 \pm 8 \cdot 9 \\
2 \cdot 4 \pm 1 \cdot 2 \\
1 \cdot 4 \pm 1 \cdot 1 \\
2 \cdot 2 \pm 1 \cdot 7 \\
2 \cdot 4 \pm 1 \cdot 6 \\
1 \cdot 2 \pm 0 \cdot 7\end{array}$ \\
\hline
\end{tabular}

${ }^{1}$ Measured by electroimmunoassay. 
patients than in sputum sol phase from patients with bronchitis but the values did not differ significantly from the corresponding average concentrations in sputum from patients with asthma. These differences in the average concentrations of the six plasma proteins are illustrated in Figure 2.

The sputum $\beta_{1 \mathrm{c}}$ globulin concentrations did not differ significantly between specimens from group

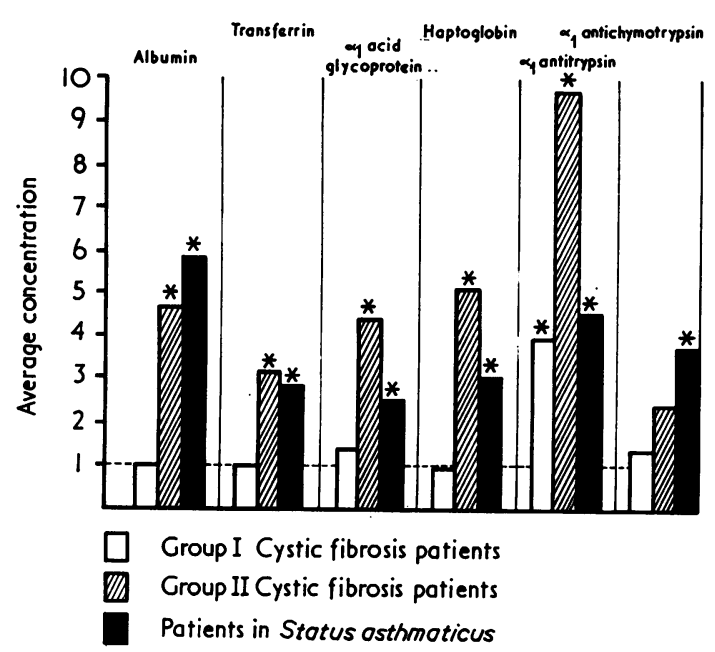

FIG. 2. Illustrations of the similarities and differences between the average concentrations of six plasma proteins in the sol phase of sputum from patients with cystic fibrosis (groups I and II), asthma, and chronic bronchitis. The average concentrations of the plasma proteins in the sputum sol phase of patients with bronchitis have been counted as unity (dotted line) and the heights of the columns show the average plasma protein concentrations relative to those in sputum from the bronchitic patients. Asterisks denote concentrations significantly different from those in bronchitic sputum.
II CF patients and from patients with asthma but the average concentrations were significantly higher $(P<0.001)$ in sputum from group II CF patients than in sputum from group I CF patients or from patients with bronchitis (Table II). The concentrations in sputum of the secretory proteins, lactoferrin and lysozyme, did not differ in specimens from patients with cystic fibrosis, asthma or bronchitis but the average $\operatorname{IgA}$ level in sputum from group I CF patients and from patients with asthma was significantly lower than that in sputum from patients with bronchitis $(\mathrm{P}<0.001)$. In group II CF patients the sputum IgG levels were significantly higher $(P<0.001)$ than those of sputum specimens from group I CF patients or from patients with asthma or bronchitis. Differences between the levels in sputum of these proteins with potential antimicrobial activity are illustrated in Figure 3.

VARIANCE IN RESULTS IN INDIVIDUAL PATIENTS WITH CYSTIC FIBROSIS An average of seven consecutive sputum specimens were obtained from nine individual patients in groups I and II and specimen to specimen variation was compared with patient to patient variation in the concentrations of six representative soluble sputum proteins (Table III). In group I CF patients, none of the average concentrations of the proteins in three out of four individual patients differed significantly from those of the corresponding average levels in sputum specimens from the group of 11 patients. In one patient (F.C.), the average sputum $\alpha_{1}$ antitrypsin concentration was significantly greater than that in the specimens from the mixed group $(P<0.001)$ and the only other values that differed were the average concentrations of $\alpha_{1}$ acid glycoprotein and IgG, both of which were just significantly greater than

T A B L E I I

CONCENTRATIONS OF SOLUBLE PROTEINS WITH POTENTIAL ANTIMICROBIAL ACTIVITY IN THE SOL PHASE OF SPUTUM FROM CYSTIC FIBROSIS PATIENTS COMPARED WITH THOSE OF SPUTUM FROM PATIENIS WITH ASTHMA AND CHRONIC BRONCHITIS

\begin{tabular}{|c|c|c|c|c|}
\hline \multirow[b]{3}{*}{ Soluble Protein } & \multicolumn{4}{|c|}{ Average Concentrations $(\mathrm{mg} / 100 \mathrm{ml})$ in the Sol Phase } \\
\hline & \multicolumn{2}{|c|}{ Sputum from Patients with Cystic Fibrosis } & \multicolumn{2}{|c|}{ Sputum from Patients with Asthma and Bronchitis } \\
\hline & $\begin{array}{c}\text { Group I } \\
\text { (15 patients) } \\
\text { Mean } \pm \text { SD }\end{array}$ & $\begin{array}{c}\text { Group II } \\
\text { (14 patients) } \\
\text { Mean } \pm \text { SD }\end{array}$ & $\begin{array}{c}\text { Asthma } \\
\text { (12 patients) } \\
\text { Mean } \pm \text { SD }\end{array}$ & $\begin{array}{c}\text { Bronchitis } \\
\text { (12 patients) } \\
\text { Mean } \pm \text { SD }\end{array}$ \\
\hline $\begin{array}{l}\beta_{1 \mathrm{c}} \text { globulin } \\
\text { Lactoferrin }^{1} \\
\text { Lysozyme }^{1} \\
\text { IgA }^{2} \\
\text { IgG }^{1}\end{array}$ & $\begin{array}{l}1 \cdot 0 \pm 0.8 \\
26 \pm 30.6 \\
34 \pm 10 \cdot 1 \\
20 \pm 16 \cdot 3 \\
27 \pm 28 \cdot 1\end{array}$ & $\begin{array}{r}3 \cdot 3 \pm 2 \cdot 5 \\
50 \pm 50 \cdot 1 \\
46 \pm 18 \cdot 7 \\
50 \pm 87 \cdot 2 \\
121 \pm 71 \cdot 1\end{array}$ & $\begin{array}{l}2 \cdot 3 \pm 1 \cdot 4 \\
27 \pm 14 \cdot 5 \\
46 \pm 25 \cdot 7 \\
14 \pm 7 \cdot 8 \\
34 \pm 26 \cdot 3\end{array}$ & $\begin{array}{r}1 \cdot 0 \pm 0 \cdot 7 \\
27 \pm 23 \cdot 0 \\
43 \pm 27 \cdot 6 \\
76 \pm 41 \cdot 9 \\
17 \pm 9 \cdot 7\end{array}$ \\
\hline
\end{tabular}

1 Measured by electroimmunoassay.

${ }^{2}$ Estimated as $7 \mathrm{~S}$ globulin. 


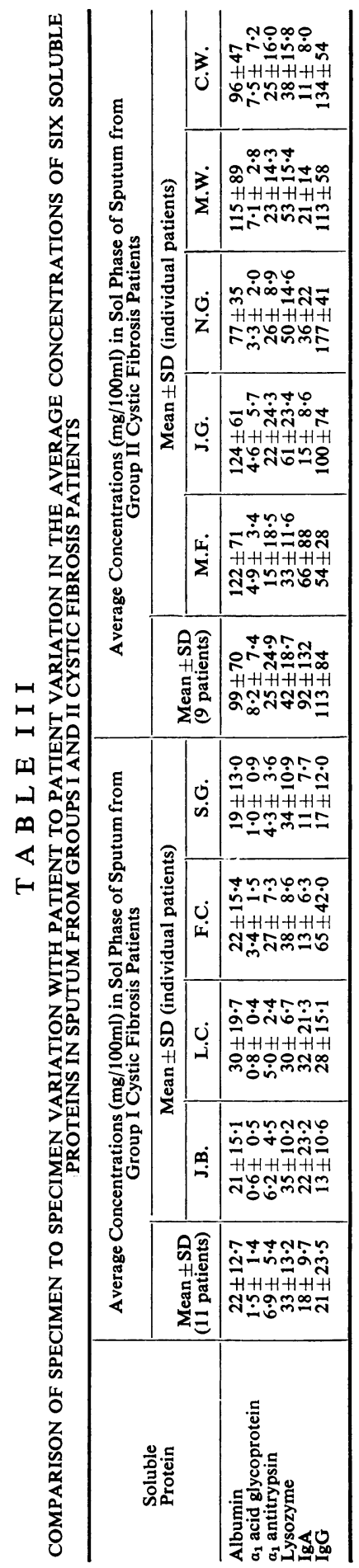




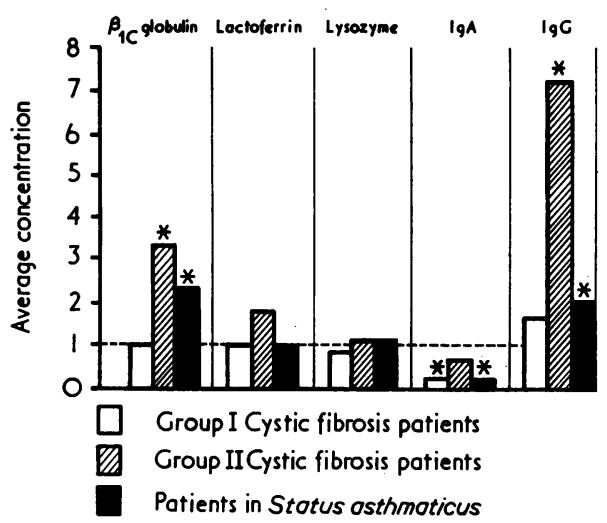

FIG. 3. Illustration of the similarities and differences between the average concentrations of five soluble proteins with potential antimicrobial activity in the sol phase of sputum from patients with cystic fibrosis (groups I and II), asthma, and chronic bronchitis. The average concentrations of the soluble proteins in the sol phase of sputum from the patients with bronchitis have been counted as unity (dotted line) and the heights of the columns show the average protein concentrations relative to those in sputum from the bronchitic patients. Asterisks denote concentrations significantly different from those in bronchitic sputum.

the corresponding values in sputum specimens from the mixed group $(0.01<\mathrm{P}<0.02)$.

In group II $\mathrm{CF}$ patients, the only sputum protein levels that differed significantly between any individual patient and the group of nine patients were the lysozyme concentration of sputum specimens from J.G. and the IgG concentration of specimens from N.G.; both values were just significantly greater than the corresponding concentrations of these proteins in specimens from the mixed group $(0.02<p<0.05)$. None of the other values differed significantly between any individual patient and the mixed group.

\section{DISCUSSION}

Bronchopulmonary secretions of the healthy human subject are rarely available for study since intubation in itself causes inflammation; their composition can therefore be deduced only by extrapolation from studies on sputum and saliva. The same soluble secretory proteins are found in sputum and saliva although, apart from amylase, their concentrations are greater in sputum than in saliva (Ryley, 1972). The only plasma proteins in saliva are low concentrations of albumin and $\operatorname{IgA}$ and traces of haptoglobin
(Ryley and Brogan, 1973). Thus it would appear that the inevitable admixture of saliva with sputum, in spite of precautions we have described hitherto (Ryley and Brogan, 1968), would affect the concentrations of the soluble proteins of sputum only by causing dilution.

Analysis of the soluble sputum proteins suggested that the population of CF patients that we were studying was not homogeneous but could be separated into two groups. Students $t$ test was used to assess in terms of probability whether or not the two groups were drawn from the same population. Differences in the average sputum sol phase concentrations of albumin, transferrin, the acute phase proteins, $\alpha_{1}$ antitrypsin, $\beta_{10}$ globulin, and IgG all yielded values of $t$ which indicated that the probability of the two groups of specimens originating from the same series of patients was less than $1: 1,000$. Investigation of specimen to specimen variation in a number of individual patients from each group showed that the average levels of the plasma proteins that appeared to be characteristic of the group were maintained consistently by individual patients when consecutive specimens were examined over a period of time. There would thus seem to be some validity in our assigning patients to these separate categories.

Concentrations of the majority of the soluble proteins in sputum specimens from group I CF patients and from patients with bronchitis were closely similar; the average concentration of $\alpha_{1}$ antitrypsin was greater in sputum from group I CF patients than in that of patients with bronchitis, suggesting selective concentration of this enzyme inhibitor. In contrast, the average IgA concentration in sputum from group I CF patients was significantly less than the sputum IgA concentrations of patients with bronchitis and resembled the sputum levels of patients with asthma. Interpretation of these differences, however, demands caution since the protein was estimated as $7 \mathrm{~S}$ globulin and could have been an underestimate of the true concentration as sputum sol phase $\operatorname{IgA}$ is a mixture of $7 \mathrm{~S}$ and secretory IgA.

In group II CF patients, the average concentrations of sputum plasma proteins were closely similar to those of the patients with severe asthma. Average sputum $\operatorname{IgA}$ concentrations in this CF group were not significantly different from those of patients with bronchitis but the average IgG levels were high and exceeded those in sputum specimens from group I CF patients and from the patients with asthma and bronchitis. Martinez- 
Tello, Braun, and Blanc (1968) demonstrated that there is an increase in the numbers of plasma cells producing both IgA and IgG within the submucosal stroma between the bronchial glands in cystic fibrosis patients with severe bronchopulmonary inflammation. It is thus possible that the submucosal plasma cells were responsible in part for the high sputum concentrations of IgG in group II CF patients.

The finding of two distinct groups of CF patients was puzzling since the groups did not differ substantially from one another in clinical status. The similarity between the bronchial secretion in group II CF patients and patients with severe asthma would seem to suggest that a pulmonary hypersensitivity reaction was occurring in this group of cystic fibrosis patients. It is known that patients with cystic fibrosis are capable of a humoral immune response expressed as precipitating antibodies to bacterial antigens such as Haemophilus influenzae and Pseudomonas aeruginosa (Burns and May, 1968). It is likely, therefore, that cystic fibrosis patients are also capable of producing antibodies to a variety of inhaled or ingested antigens, and in some patients immune complexes may develop which, in turn, could lead to pulmonary allergy. The association between precipitating antibodies and chronic respiratory disease in some patients with milk allergy has been known for some years (Heiner, Sears, and Kniker, 1962). This raises the issue as to whether exhibition of corticosteroids or other anti-inflammatory drugs might be indicated in group II CF patients since intrabronchial inflammation of an intensity comparable with severe asthma could be detrimental.

A marked feature of our investigation is the finding that secretory proteins with antimicrobial activity such as lactoferrin and lysozyme were present in CF mucus in concentrations that were closely similar to those in sputum from patients with asthma and bronchitis. Similarly, there was evidence that the two antiproteases, $\alpha_{1}$ antitrypsin and $\alpha_{1}$ antichymotrypsin, were in fact selectively concentrated in the bronchial mucus of all patients with cystic fibrosis. Above average susceptibility to chest infection in cystic fibrosis, therefore, does not appear to be explicable in terms of deficiency of secretory proteins such as bronchial lysozyme or failure to produce adequate concentrations of antiproteases or immunoglobulins within the bronchial lumen. The question therefore arises whether the mucus glycoproteins interfere with the action of local humoral and cellular defence mechanisms. The resistance-lowering properties of mucins have been the subject of much work in the past, as can be seen from the review by Olitzski (1948) but little is yet known about their precise mod $\overline{8}$ of action. Patients with cystic fibrosis probably have an impaired mucociliary clearance mechanism due to the action of the cilia $\vec{\Phi}$ dyskinesia factor (Spock et al., 1967); thus the $\overrightarrow{\mathrm{L}}$ may be more dependent than other patients witis chronic chest diseases on the efficiency of the local pulmonary host defence mechanisms Bronchial glycoproteins have been shown to be anticomplementary and to interfere with phago $\overrightarrow{-}$ cytosis (Brogan, 1964); it is therefore possible that resistance-lowering mechanisms such as these may be the limiting factors in determining susceptibility to chest infection in cystic fibrosis.

We thank Professor Scott Thomson of the Depart ment of Medical Microbiology for his continuing interest in our work and those physicians of the Soutk Glamorgan Area Health Authority who allowed uṣr access to patients under their care. The work was supported by grants from the Cystic Fibrosis $\operatorname{Re} \stackrel{\text { S }}{s}$ search Trust, The Medical Research Council, and the Welsh Hospital Board.

\section{REFERENCES}

Andersen, D. H. (1938). Cystic fibrosis of the pan $\frac{0}{3}$ creas and its relation to celiac disease: A clinicopathologic study. American Journal of Diseases of Children, 56, 344.

Brogan, T. D. (1964). Effect of complement and of the carbohydrate components of sputum on phagocytosis by human polymorphonuclearx leucocytes. Immunology, 7, 626.

Burns, M. W. and May, J. R. (1968). Bacterial pre cipitins in serum of patients with cystic fibrosis $\varrho$ Lancet, 1, 270.

Clarke, H. G. M. and Freeman, T. (1968). Quantitative immunoelectrophoresis of human serum proteins. Clinical Science, 35, 403.

Cooperman, E. M., Park, M., McKee, J., and Assad, J. P. (1971). A simplified cystic fibrosis scoring system. Canadian Medical Association Journal;
105, 580.

Heiner, D. C., Sears, J. W., and Kniker, W. T. (1962).స్ Multiple precipitins to cow's milk in chronico respiratory disease. American Journal of Diseases of Children, 103, 634.

Lopez, M., Tsu, T., and Hyslop, N. E. Jr (1969). Studies of electroimmunodiffusion: Immuno-chemical quantitation of proteins in dilute solu- $T$ tions. Immunochemistry, 6, 513.

Martinez-Tello, F. J., Braun, D. G., and Blanc, W. A. (1968). Immunoglobulin production in bronchial mucosa and bronchial lymph nodes, particularly $\varrho$ in cystic fibrosis of the pancreas. Journal of Immunology, 101, 989. 
May, J. R. (1958). In Recent Trends in Chronic Bronchitis, edited by N. C. Oswald, p. 96. Lloyd Luke, London.

MRC Committee on the Aetiology of Chronic Bronchitis (1965). Lancet, 1, 775.

Olitzski, L. (1948). Mucin as a resistance-lowering substance. Bacteriological Reviews, 12, 149.

Ryley, H. C. (1972). An immunoelectrophoretic study of the soluble secretory proteins of sputum. Biochimica and Biophysica Acta, 271, 300.

- and Brogan, T. D. (1968). Variation in the composition of sputum in chronic chest diseases. British Journal of Experimental Pathology, 49, 625.
- and - (1973). Quantitative immunoelectrophoretic analysis of the plasma proteins in the sol phase of sputum from patients with chronic bronchitis. Journal of Clinical Pathology, 26, 852.

Spock, A., Heick, H. M. C., Cress, H., and Logan, W. S. (1967). Abnormal serum factor in patients with cystic fibrosis of the pancreas. Pediatric Research, 1, 173.

Requests for reprints to: Dr. T. D. Brogan, Department of Medical Microbiology, Welsh National School of Medicine, University Hospital of Wales, Cardiff. 